\title{
STRUCTURAL RELIABILITY-BASED ASSESSMENT OF NIGERIAN ANOGEISSUSSCHIMPERI TIMBER BRIDGE BEAM IN SHEAR AND BEARING FORCES
}

\author{
P. Abubakar ${ }^{1,}{ }^{*}$, A. Iorkar ${ }^{2}$, A. A. Adedeji ${ }^{3}$, J. I. Aguwa ${ }^{4}$ and U. N. Wilson ${ }^{5}$ \\ 1, 2, 3, DePARTMENT OF CIVIL ENGINEERING, UNIVERSITY OF ILORIN, ILORIN, KWARA STATE, NIGERIA. \\ 4, DePt of Civil Engineering, Federal University of TeChnology, MinNa, Niger State, NIGERIA. \\ 5. Department OF Civil Engineering, Nigerian Defense Academy, Kaduna, Kaduna State, NIGERIA. \\ E-mail addresses: ${ }^{1}$ philip.abubakar@yahoo.com ${ }^{2}$ iorkar@yahoo.com, 3 gaiadeji@gmail.com, \\ 4jiaguwa@yahoo.com, 5 unwilson@nda.edu.ng
}

\begin{abstract}
This research investigates the reliability of Anogeissus schimperi timber specie grown in North Western Nigeria as a bridge beam in shear and bearing forces. Specimens for laboratory tests were prepared using the timber specie in accordance with BS 373 (1957). Tests were carried out to determine the physical and mechanical properties at $12 \%$ moisture content in line with BS 5268 (2002). Statistical analysis was carried out using strength properties obtained and the specie was classified to strength class D60, confirmed to be Hardwood. Anogeissus schimperi timber bridge beam was designed in accordance to BS5268 (2002), using deterministic approach. While, reliability analysis to confirm the safety level of the timber bridge beam designed was carried out using constant failure rate model in accordance with Jimoh, (2018). Sensitivity analysis to ascertain the safety margin of a simply supported timber bridge beam subjected to Shear and bearing by varying the span, depth, width and live load was carried out. Results of reliability analysis showed that Anogeissus schimperi met the minimum reliability index of 0.5 under ultimate state of loading in Shear and bearing. Safety index was found to be directly proportional to the depth and width but inversely proportional to the span and live load of the timber bridge beam during Sensitivity Analysis. The result confirmed that Anogeissus schimperi specie from north western Nigeria at $400 \mathrm{~mm}$ depth, $150 \mathrm{~mm}$ breadth and $5000 \mathrm{~mm}$ span under ultimate limit state loading in Shear and bearing can be used as a reliable timber bridge beam material.
\end{abstract}

Keywords: Bridge Beam, Nigerian Anogeissus schimperi Reliability, Structural Material, Timber, Ultimate Limit State.

\section{INTRODUCTION}

Reliability analysis has continued to develop a growing importance in modern structural engineering application especially when it comes to natural occurring materials like timber [1]. However, research on reliability of timber is complex due to its large natural variability. Also the uncertainty about the behavior of local timber species in Nigeria when loaded is one of the factors that discourage many Engineers from timber designs. Reliability is the probability that a system would perform adequately for at least a specified period of time under specified operating conditions [2]. Structural performance of bridge beam is determined by loads and resistance which are random variables. Therefore, reliability analysis will be required to evaluate the design provisions. The reliability index, $\beta$ is considered as measure of safety [3]. Structural Reliability is the rational assessment of uncertainties that could arise on structures when in use [4].

* Corresponding author: $+234-816-870-60$ 
The most important processes in structural analysis are the determination of the structural behavior based on structural types and variables with sufficient examination of the effects on the whole structure [5].The use of European and British codes in our structural timber design is unprofessional. This is because the strength properties used were for trees from their countries and the laboratory tests conducted were done under their environment and weather conditions different from Nigerian weather. In line with [1] it is justifiable to carry out detailed laboratory tests on our own locally grown timber to ascertain their structural reliability and performance. Nigeria has varieties of timber species that are predominantly in the eastern and southern region. The demand for timber in the northern region is ever increasing due to the increase in population growth. North western region depends on timber from the south western region, hence the high cost of the commodity [6]. Some known species are already going on extinction and urbanization is negatively affecting the natural growth rate of indigenous savanna tree species, hence the need to conduct research to ascertain the Reliability of timber species that are locally available in north western region.

The aim of this study is to evaluate the structural reliability of Anogeissus schimperi in shear and bearing as a Bridge Beam .The specific objectives are:(i) to determine the strength properties of Anogeissus schimperi timber specie, (ii) to carryout statistical analysis on the strength properties determined and obtain a deterministic design of the timber bridge, (iii) to check the structural reliability of the timber bridge Beam subjected to Shear and bearing and carry out sensitivity analysis to ascertain the safety margin of a simply supported Anogeissus schimperitimber bridge beam subjected to Shear and bearing by varying the span, depth, width and live load.

\section{MATERIALS AND METHOD}

\subsection{Materials}

Anogeissus schimperispecie was collected from logs cut from stem portion of felled trees in Kaduna, Katsina and Zamfara States, and sawn into $100 \mathrm{~mm}$ $x 300 \mathrm{~mm} \times 3600 \mathrm{~mm}$. Logs free from all forms of defects were carefully selected and conveyed to Civil Engineering Laboratory, University of Ilorin for Seasoning and Preparation of Specimens.

\subsection{Method}

Test specimens were prepared in Civil Engineering Laboratory, University of Ilorin in accordance with [7], 20 samples were prepared for each test making a total of 120 samples. Seasoning of the specie was done using natural air for seven months in Civil Engineering Laboratory, University of Ilorin in accordance with [7]. Laboratory Tests for determination of Strength properties were carried out at the Department of Agricultural Engineering, University of Ilorin, Kwara State, using a Universal Testing Machine.. Laboratory tests carried out were Shear parallel to the grain, tension parallel to grain, compression parallel to the grain, compression perpendicular to the grain, Shear parallel to grain, modulus of elasticity and density at naturally seasoned moisture content.

\subsubsection{Density of the specie}

The density of Anogeissus schimperi specie was obtained using Equation (1). The masses of 20 samples of dimension $20 \mathrm{~mm}$ by $20 \mathrm{~mm}$ by $20 \mathrm{~mm}$ were determined and average mass obtained and its volume computed from the sizes of the sample.

$$
\rho=\frac{M}{V}
$$

Where, $\mathrm{M}=$ mass of the sample, $\mathrm{V}=$ Volume of sample.

\subsubsection{Density value at $12 \%$ moisture content}

The density obtained during the shear tests in $\mathrm{kg} / \mathrm{m} 3$ was adjusted to value at $12 \%$ moisture content, and was used for classification of timber specie. Equation (2) was used for the adjustment.

$$
\mathrm{P}_{\mathrm{k} 12 \%}=\mathrm{P}_{\mathrm{w}}\left[1-\frac{(1-0.5)(\mathrm{U}-12)}{100}\right]
$$

Where $\mathrm{Pk} 12 \%$ is density at $12 \%$ moisture content in $\mathrm{kg} / \mathrm{m} 3, \mathrm{Pw}=$ density of the moisture content during shear test and $U=$ measure of moisture content in \%.

\subsubsection{Modulus of Elasticity}

Modulus of elasticity was computed using Equation (3) which is the classical equation of strength of materials applied to straight beams for 3-point shear. This is in conformity with the method used by [8] to compute modulus of elasticity.

$$
\mathrm{EL} 3=\frac{L^{3}}{4 e h^{3}} k
$$

Where, $\mathrm{L}=$ Span, $\mathrm{e}=$ width, $\mathrm{h}=$ depth, $\mathrm{k}=\frac{\Delta p}{\Delta f}$, $\Delta \mathrm{P}=$ Change in applied load. 
$\Delta f=$ Change in bearing at mid span

\subsubsection{Modulus of elasticity values at $12 \%$ moisture content (mc)}

Modulus of elasticity values obtained were adjusted to values at $12 \%$ moisture content in accordance with codes, for timber classification. Equation (4) was used for the adjustment. $[6,9]$.

$$
\mathrm{E}_{\mathrm{m} 12 \%}=\frac{\mathrm{E}_{\text {measured }}}{1+0.0143(12-\mathrm{U})}
$$

Where; $\mathrm{E}$ measured = measured modulus of elasticity, $\mathrm{U}=$ measured moisture content in $\%$ and Em12\% = Modulus of elasticity at $12 \%$ moisture content

\subsubsection{Strength properties adjustment}

Strength values of timber species were taken at $12 \%$ moisture content, as reference moisture content in line with the requirement of [10].[11],[9]. Increase in moisture content of timber from zero to fiber saturation point ( $27-30 \%)$, causes reduction in strength properties of timber. No further reduction in strength properties was observed, when the moisture content increased beyond the saturation point $[2,12]$. Tests results of [13] indicated that the equilibrium moisture content of the species were above $12 \%$. Hence the need for adjustment to results at $12 \%$ reference moisture content.

\subsubsection{Strength Properties at 12\% moisture content.}

Strength properties obtained during laboratory tests at varying moisture contents were adjusted to $12 \%$ moisture content in accordance with [9]. Equation (5) was used.

$$
\mathrm{F}_{12}=\mathrm{F}_{\mathrm{w}}+\alpha(\mathrm{w}-12)
$$

Where; $\mathrm{F} 12=$ strength at $12 \%$ moisture content, $\mathrm{Fw}=$ Strength at experimental moisture content $\mathrm{w}=$ Experimental moisture content, $\mathrm{a}=$ Modification Factor (Shear $=0.04$, Compression $=$ 0.05 , Shear $=0.03$ and tension $=0.05)[14]$

\subsubsection{Basic shear stresses}

Basic stresses were computed from failure stresses recorded in the laboratory experiments using Equation (6) in accordance with [15].

$$
\mathrm{F}_{\mathrm{b}}=\frac{\mathrm{f}_{\mathrm{m}}-\mathrm{K}_{\mathrm{p}} \sigma}{\mathrm{K}_{\mathrm{r}}}
$$

Where $\mathrm{Fb}=$ Basic stress, $\mathrm{Fm}=$ Mean value of the failure stress from test, $\sigma=$ Standard deviation, $\mathrm{Kr}$
$=$ reduction factor (Shear, tension and Shear parallel to the grain $=2.25$, compression parallel to the grain $=1.4$ and compression perpendicular to the grain $=1.2)[14]$ and $\mathrm{Kp}=$ modification factor $=$ 2.33

\subsubsection{Deterministic design of anogeissus schimperi timber bridge beam to BS 5268}

Table 1 show the general design parameter used in the deterministic design of the Anogeissus schimperi timber bridge beam.

\subsubsection{Reliability analysis}

Reliability, $\mathrm{R}(\mathrm{t})$ of an element is defined as the ability of an element to perform the required function under stated conditions without failure for a stated period. It is the rational assessment of uncertainties that could arise on structures when in use. The uncertainties usually built into the design variables through deterministic analysis, always make it difficult to perfectly understand the behaviour of structures. Structural design is mainly to evaluate the expected performance of a structural element in terms of safety and functionality [4].

Reliability analysis in this research was carried out using constant failure rate (CFR) models. The Reliability index was obtained from constant failure rate model in accordance with [17] and [18] as given in Equation (7).

$$
\mathrm{R}(\mathrm{t})=e^{-\lambda \mathrm{t}} A
$$

Where: $R(t)$ is reliability index, $\lambda$, is the constant rate of failure and $t$, is the variable time of failure. The constant rate of failure $\lambda$ is given by;

$$
\begin{aligned}
\lambda & =\frac{1-d}{T} \\
Q_{i} & =\sum_{j=1}^{i}\left(\sigma_{i}\right) \\
R_{i} & =\sum_{i} \sigma-Q_{i} \\
d_{i} & =\frac{\sigma_{i}}{R_{i-1}} \\
d & =\sum_{i} \frac{d_{i}}{n} \\
R_{i} & =\sum_{i} \tau-Q_{i} \\
R_{i} & =\sum_{i} \sigma-Q_{i}, \text { For bearing } \\
Q_{i} & =\sum_{j=1}\left(\tau_{v p i}\right), \text { For shear }
\end{aligned}
$$


Structural Relability-Based Assessment of Nigerian Anogeissusschimperi Timber Bridge Beam in Shear Bearing, P. Abubakar, et al

$$
Q_{i}=\sum_{j=1}^{i}\left(\sigma_{\mathrm{c} 90 \mathrm{i}}\right) \text {, For bearing }
$$

where: $\sigma_{\mathrm{i}}=$ average strength $(\mathrm{N} / \mathrm{mm} 2)$,

$\mathrm{Q}_{\mathrm{i}}=$ cumulative strength $(\mathrm{N} / \mathrm{mm} 2)$,

$\mathrm{R}_{\mathrm{i}}=$ remaining strength (\%),

$\mathrm{T}=$ time (years),

the expected life span and

$\mathrm{d}=$ the average strength rate for Shear and bearing.

From Equations (8) to (12) Equation (7) becomes equations (17) and (18) for constant failure rate reliability analysis of timber bridge beam subjected to shear and bearing forces.

$$
\begin{aligned}
& R(t)=e^{-\left[\frac{1-\sum \frac{\tau_{p v i}}{n R_{i-1}}}{T}\right] t} \\
& R(t)=e^{-\left[\frac{1-\sum \frac{\sigma_{c 90 i}}{T} R_{i-1}}{T}\right] t}
\end{aligned}
$$

\subsubsection{Sensitivity analysis}

The sensitivity analysis on safety margin of Anogeissus schimperi timber bridge beam in Shear and bearing was conducted as follows.

Safety Margin in Shear: The applied shear stress, $\tau_{v a}$ due to the applied load at ultimate limit state is given by

$$
\tau_{v a}=\frac{3 V}{2 b h}
$$

where Vis the applied shear force at ULS given as

$$
V=\frac{W_{u l s} L}{2}=\frac{q_{u l s} L}{2}
$$

Equation (20) assumed that the contribution of dead load to total ultimate load is very small and can be ignored.

The permissible shear stress, $\tau_{v p}$ is given by

$$
\tau_{v p}=\frac{f_{v k} \times k_{3} \times k_{4}}{\gamma_{m}}=\frac{1.21 \mathrm{~N}}{\mathrm{~mm} 2(\mathrm{BS} 5268) v}
$$

Therefore safety margin in shear,

$$
f_{\tau s}=\frac{\tau_{v p}}{\tau_{v a}}=\frac{4.84 b h}{3 L q_{u l s}} \geq 1
$$

\subsubsection{Safety margin in bearing}

The applied bearing stress, $\sigma_{c 90}$ a perpendicular to the grain is given by:

$$
\sigma_{c 90 a}=\frac{3 V}{2 b L_{x}} \text { (BS5268) }
$$

Where $\mathrm{V}$ is the applied shear force at ULS given as

$$
V=\frac{W_{u l s} L}{2}=\frac{q_{u l s} L}{2}
$$

Equation (24) assumed that the contribution of dead load to total ultimate load is very small and can be ignored. The permissible shear stress, $\tau_{v p}$ is given by:

$$
\sigma_{c 90 p}=\frac{f_{c 90 k} \times k_{3} \times k_{6} \times k_{7}}{\gamma_{m}}=\frac{24.51 \mathrm{~N}}{\mathrm{~mm}^{2}}
$$

Therefore, safety margin in bearing,

$$
f_{\sigma c s}=\frac{\sigma_{c 90 p}}{\sigma_{c 90 a}}=\frac{98.04 b L_{x}}{3 L q_{u l s}} \geq 1
$$

\begin{tabular}{|c|c|c|}
\hline Parameters & Symbols & Value Used \\
\hline $\begin{array}{l}\text { Width of the bridge } \\
\text { carriageway }\end{array}$ & B & $7000 \mathrm{~mm}$ \\
\hline $\begin{array}{l}\text { Number of the Notional } \\
\text { lane }\end{array}$ & $\mathrm{N}$ & 2 \\
\hline Notional lane width & Lw & 3.5 \\
\hline HA loading & HA & $30 \mathrm{KN}$ \\
\hline $\begin{array}{l}\text { Uniformly distributed } \\
\text { HA,udl }\end{array}$ & HA,udl & $8.57 \mathrm{KN} /$ lane \\
\hline Knife edge loading & KEL & $120 \mathrm{KN}$ \\
\hline Uniformly distributed KEL & KEL,udl & $34.29 \mathrm{kNm}$ \\
\hline $\begin{array}{l}\text { Acceleration due to } \\
\text { gravity }\end{array}$ & G & $10 \mathrm{~m} / \mathrm{s} 2$ \\
\hline Timber plank thickness & $\mathrm{Hp}$ & $100 \mathrm{~mm}$ \\
\hline Spacing of the beam & $\mathrm{Sb}$ & $400 \mathrm{~mm}$ \\
\hline Beam depth & H & 400mm \\
\hline Span of the beam & L & $5000 \mathrm{~mm}$ \\
\hline Beam width & B & $150 \mathrm{~mm}$ \\
\hline Safety factor for material & ym & 1.3 \\
\hline $\begin{array}{l}\text { Safety factor for } \\
\text { permanent action at ULS }\end{array}$ & ya,uls & 1.35 \\
\hline $\begin{array}{l}\text { Safety factor for variable } \\
\text { action at ULS }\end{array}$ & $\gamma Q$, uls & 1.5 \\
\hline $\begin{array}{l}\text { Safety factor for } \\
\text { permanent action SLS }\end{array}$ & ya,sls & 1.0 \\
\hline $\begin{array}{l}\text { Safety factor for variable } \\
\text { action at SLS }\end{array}$ & rQ,sls & 1.0 \\
\hline $\begin{array}{l}\text { Factor for duration of } \\
\text { loading }\end{array}$ & K3 & 1.5 \\
\hline Form factor & K6 & 1.4 \\
\hline $\begin{array}{l}\text { Modification factor for } \\
\text { bearing stress }\end{array}$ & K4 & 1.0 \\
\hline Depth modification factor & K7 & 1.0 \\
\hline
\end{tabular}

The reference and variable parameters used in the sensitivity analysis of safety margin of Anogeissus schimperi timber bridge beam in shear and bearing to change in design variable is as presented in Table 2. By varying the design variables, one at a time, the effect of each variable for Shear and bearing on safety margin of Anogeissus schimperi timber species were determined.

Table 1: General Input Parameters for the Design of the Timber Beam 
Table 2: Variables used in Sensitivity Analysis

\begin{tabular}{llllll}
\hline Parameters & Span, $\mathrm{L}(\mathrm{mm})$ & $\begin{array}{l}\text { Bearing length, } \\
\mathrm{Lx}(\mathrm{mm})\end{array}$ & Depth, $\mathrm{h}(\mathrm{mm})$ & Width, $\mathrm{b}(\mathrm{mm})$ & $\begin{array}{l}\text { Ultimate live load, } \\
\text { quls }(\mathrm{kN} / \mathrm{m})\end{array}$ \\
\hline Reference value & 5000 & 300 & 400 & 150 & 8.58 \\
Upper limit & 7200 & 300 & 510 & 310 & 15.5 \\
Lower limit & 3000 & 300 & 300 & 100 & 5 \\
\hline
\end{tabular}

\section{RESULTS AND DISCUSSIONS}

\subsection{Mean Mass, Mean Density, Mean Modulus of Elasticity and Moisture Content}

Table 3 presents the masses of test specimens of Anogeissus schimperi obtained and the computed mean densities. 20 samples were used and the sizes of specimens were $20 \mathrm{~mm} \times 20 \mathrm{~mm} \times 20 \mathrm{~mm}$. The mean mass and mean density, mean modulus of elasticity obtained were $7.8 \mathrm{~g}, 951 \mathrm{Kg} / \mathrm{m} 3$ and $20,269 \mathrm{~N} / \mathrm{mm} 2$ respectively. The average moisture content of Anogeissus schimperi samples used for the experiments was $18 \%$.

\subsection{Mean Failure Stress, Basic Stress and Grade Stress}

Table 4 presented mean failure stress, standard deviation, basic stresses and grade stresses for shear parallel to the grain for Anogeissus schimperi specie.

\subsection{Allocation of Strength Class}

The experiments and analysis of results carried out had produced tables of characteristics stresses and physical properties of Anogeissus schimperi timber specie from North-western Nigeria in accordance with international codes.

Table 5 presents the summary of results for grade stress, mean density and mean modulus of elasticity which were used for grading of specie. In conformity with [10], which allows a solid timber to be assigned a strength class if its characteristics values of grade stress and mean density equal or exceed the value for that strength class, Anogeissus schimperi was assigned to D60 class. The specie is therefore confirmed to be Hardwood.

\subsection{Results of Deterministic Bridge Beam Design}

The timber bridge beam was analyzed and designed as simply supported beam uniformly loaded and the result is as presented in Table 6.

\subsection{Reliability Analysis}

The Reliability index was obtained using Equation (7).The constant failure rate $\lambda$ was analyzed as given in equations (8) for shear stress and bearing using [9] approach and the results as presented in Table 7.

Average strength rate in shear $d=\Sigma d / 20$

$$
\begin{aligned}
\mathrm{d}= & 0.0600+0.0962+1.0964+0.2670+0.2925 \\
& +0.3478+0.3826+0.4554+0.4793+ \\
& 0.5497+0.5863+0.6472+0.6943+0.7667 \\
& +0.7966+0.8535+0.8998+0.9574+ \\
& 0.9973+1.0000 / 20=\mathbf{0 . 5 6 6 3}
\end{aligned}
$$

Average strength rate in bearing $d=\Sigma d / 20$

$d=0.0383+0.2150+0.3710+0.4496+0.4904$

$+0.5742+0.5968+0.6753+0.6933+$

$0.7291+0.7547+0.7910+0.8452+0.8683$

$+0.8983+0.9465+0.9602+0.9833+$

$0.9914+1.0000 / 20=\mathbf{0 . 6 9 3 6}$

Taking the service life of 50 years and that all other serviceability requirements are met, the reliability of Anogeissus schimperi is evaluated using Constant Failure Rate reliability method.

Constant Failure Rate in Shear,

$$
\lambda=\frac{1-\mathrm{d}}{\mathrm{T}}=\frac{1-0.5663}{50}=0.0087
$$

Constant Failure Rate in bearing

$$
\lambda=\frac{1-\mathrm{d}}{\mathrm{T}}=\frac{1-0.6936}{50}=0.0061
$$

From the results in Tables 7 and 8, reliability analyses of timber bridge beam of Anogeissus schimperi specie subjected to shear and bearing using constant failure models (Equation 7) was computed and presented in Figure 1.

Reliability in Shear,

$$
\mathrm{R}(\mathrm{T})=e^{-0.0087 \mathrm{~T}}
$$

For $\mathrm{T}=0$ year, reliability in shear equals,

$$
\mathrm{R}(\mathrm{T})=e^{-0.0087 \times 0}=1.0000
$$

For $\mathrm{T}=5$ years, reliability in shear equals,

$$
\mathrm{R}(\mathrm{T})=e^{-0.0087 \times 5}=0.9574
$$

Reliability in bearing,

$$
\mathrm{R}(\mathrm{T})=e^{-0.0061 \mathrm{~T}}
$$

For $\mathrm{T}=0$ year, reliability in bearing equals,

$$
\mathrm{R}(\mathrm{T})=e^{-0.0061 \times 0}=1.0000
$$

For $\mathrm{T}=5$ years, reliability in bearing equals, $\mathrm{R}(\mathrm{T})=e^{-0.0061 \times 5}=0.9700$ 
Table 3: Mean Mass, Mean density, Mean modulus of Elasticity and Moisture Contents of the specie.

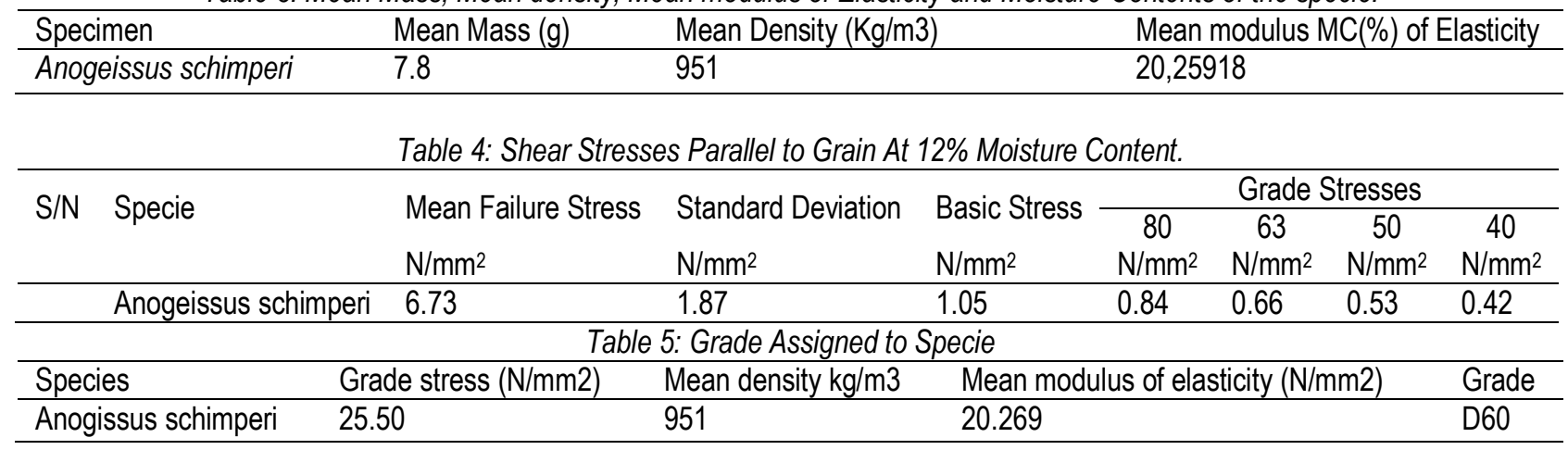

Table 6: The Results of deterministic Bridge Beam Design for the specie

\begin{tabular}{ll}
\hline Parameter & Inputvalue \\
\hline Modulus of Elasticity (mean) Emean N/mm2 & 22,171 \\
Minimum value of modulus of elasticity Emin & 16,691 \\
(N/mm2) & 951 \\
Density Pk(Kg/m3) & 0.57 \\
Unit weight of timber (KN/m3) & 1.05 \\
Grading Shear stress to grain fv,0,g. (N/mm2) \\
Grading Compressive stress to grain, fv,0,g. & 15.17 \\
(N/mm2) & 1.01 \\
Dead load (KN/m) & 8.58 \\
Live load (KN/m2 & 14.28 \\
Design load at ULS Wuls & 9.59 \\
Design load at SLS & 35.70 \\
Shear force at ULS V(KN) & 35.70 \\
Bearing force at ULS b(KN) & 0.89 \\
Design Shear stress Tv,a(N/m2) & 1.21 \\
Permissible Shear stress Tv,90,p (N/mm2) & 24.51 \\
Permissible bearing stress $\delta c, 90, p(N / m m 2)$ & \\
\hline
\end{tabular}

Table 7: Constant Failure Rate Analysis for Anogeissus schimperi timber specie in shear

\begin{tabular}{|c|c|c|c|c|}
\hline $\begin{array}{l}\text { Samp } \\
\text { le }\end{array}$ & $\begin{array}{l}\text { Shear Stress } \\
(\mathrm{N} / \mathrm{mm} 2)\end{array}$ & $\begin{array}{l}\text { Cumulati } \\
\text { ve shear } \\
\text { Stress } \\
(\mathrm{N} / \mathrm{mm} 2)\end{array}$ & $\begin{array}{l}\text { Remaini } \\
\mathrm{ng} \\
\text { shear } \\
\text { Stress } \\
\text { (N/mm2 } \\
\text { ) }\end{array}$ & $\begin{array}{l}\text { Strength } \\
\text { Rate }\end{array}$ \\
\hline 1 & 0.80 & 0.80 & 20.20 & 0.0600 \\
\hline 2 & 0.71 & 1.51 & 19.49 & 0.0962 \\
\hline 3 & 1.04 & 2.55 & 18.45 & 0.1964 \\
\hline 4 & 1.40 & 3.95 & 17.05 & 0.2670 \\
\hline 5 & 1.30 & 5.25 & 15.75 & 0.2925 \\
\hline 6 & 0.71 & 5.96 & 15.05 & 0.3478 \\
\hline 7 & 1.40 & 7.36 & 13.64 & 0.3826 \\
\hline 8 & 1.30 & 8.66 & 12.34 & 0.4554 \\
\hline 9 & 0.80 & 9.46 & 11.54 & 0.4793 \\
\hline 10 & 1.04 & 10.50 & 10.50 & 0.5497 \\
\hline 11 & 1.30 & 11.80 & 9.20 & 0.5863 \\
\hline 12 & 0.80 & 12.6 & 8.40 & 0.6472 \\
\hline 13 & 1.04 & 13.64 & 7.36 & 0.6943 \\
\hline
\end{tabular}

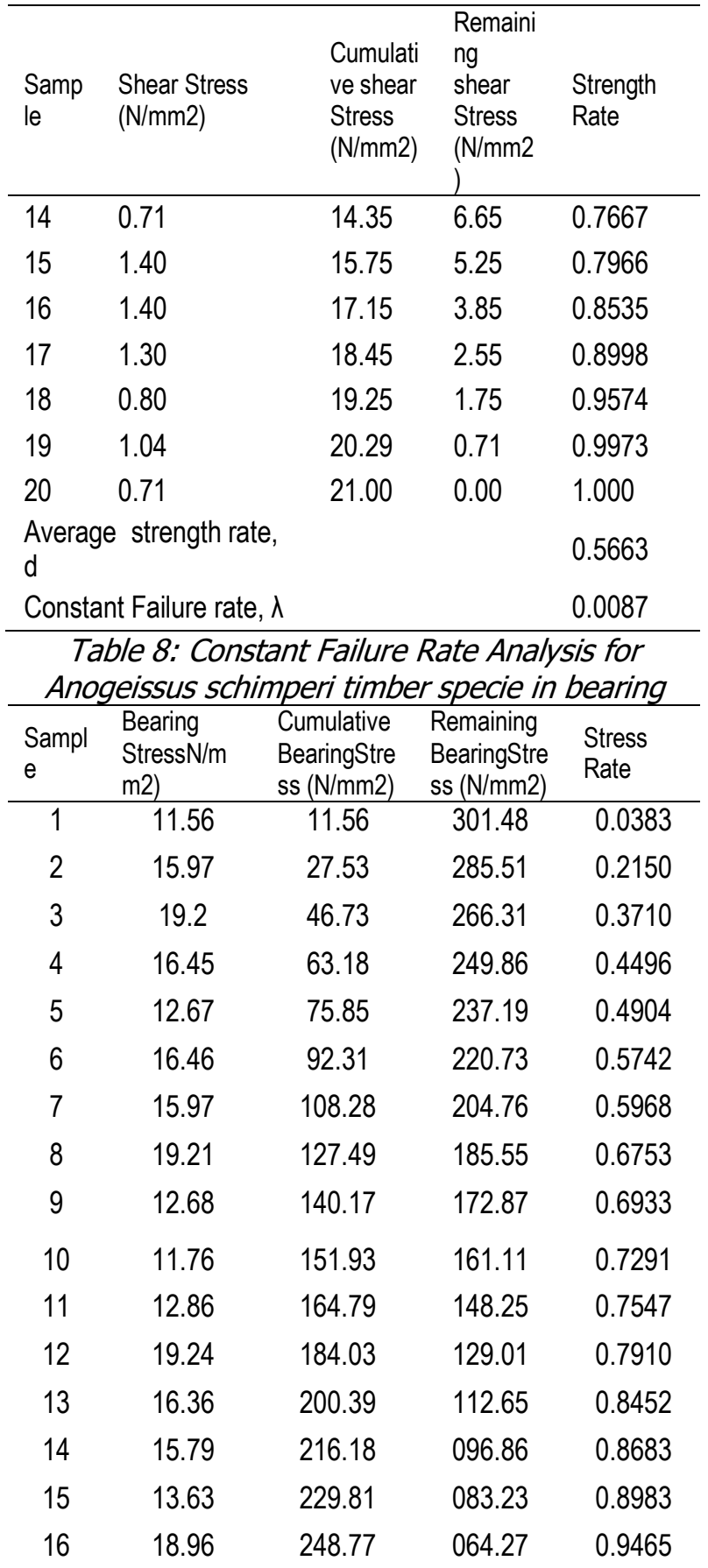




\begin{tabular}{ccccc}
\hline $\begin{array}{c}\text { Sampl } \\
\mathrm{e}\end{array}$ & $\begin{array}{l}\text { Bearing } \\
\text { Stress } / \mathrm{m} \\
\mathrm{m} 2)\end{array}$ & $\begin{array}{l}\text { Cumulative } \\
\text { BearingStre } \\
\text { ss (N/mm2) }\end{array}$ & $\begin{array}{l}\text { Remaining } \\
\text { BearingStre } \\
\text { ss (N/mm2) }\end{array}$ & $\begin{array}{l}\text { Stress } \\
\text { Rate }\end{array}$ \\
\hline 17 & 16.67 & 265.44 & 047.6 & 0.9602 \\
18 & 15.07 & 280.51 & 032.53 & 0.9833 \\
19 & 12.38 & 292.89 & 020.15 & 0.9914 \\
20 & 20.15 & 313.04 & 000.00 & 1.0000 \\
Average strength rate, d & & & 0.6936 \\
Constant Failure rate, \\
$\lambda$
\end{tabular}

\subsection{Sensitivity Analysis}

Sensitivity analysis was carried out by varying the span, width, depth, and live load for Anogeissus schimperi timber species. The results in Figures 3 to 6show the sensitivity of safety margin of a simply supported timber bridge beam subjected to Shear and bearing with variation in the span, depth, width and live load.

Figure 2, shows the sensitivity of safety margin of each of the failure modes to variation in effective span for timber bridge beam. The Figure indicated a decrease in safety margin as the effective span increased from $3000 \mathrm{~mm}$ to $7500 \mathrm{~mm}$ (See Table 8 in Appendix). In 2010, Aguwa reported that an increase in the span of a beam results in increase in shear moment which is a major factor that causes failure in beam. The timber bridge beam is safe in shear and bearing for span up to $6000 \mathrm{~mm}$ for the timber specie considered in this study. The effect of span on Safety Margin of the timber bridge beam was more significant in bearing. At the specified conditions of loading and at the span of $5000 \mathrm{~mm}$, depth of $400 \mathrm{~mm}$, width of $150 \mathrm{~mm}$ and bearing length of $300 \mathrm{~mm}$, Anogeissus schimperi specie was safe.

Figure 3shows the relationship between safety margins and depth of simply supported timber bridge beam. The results showed an increase in shear safety margin as the depth increased from $300 \mathrm{~mm}$ to $520 \mathrm{~mm}$ (See Table 9 in Appendix). The increase in safety margin could be attributed to increase in EI values which increased the rigidity of the beam. The results agreed with [19] and [20] for timber bridge beam subjected to shear force. However, the results also show that depth has no effect on the safety margin forbearing stress.

The results presented in Figure 4 show the relationship between safety margins of each of the failure modes to variation in width of simply supported timber bridge beam. The result shows an increase in safety margin as timber beam width increased from $100 \mathrm{~mm}$ to $320 \mathrm{~mm}$ (See Table 10 in Appendix) for the timber species subjected to shear and bearing forces. Relationship between safety margin and the live load for a simply supported timber bridge beam subjected to shear and bearing for timber specie in this study is shown in Figure 5. A general decrease in safety margin with increasing Live Load from $5 \mathrm{kN} / \mathrm{m}$ to $16 \mathrm{kN} / \mathrm{m}$ (See Table 11 in Appendix) was observed. This could be attributed to the fact that the carrying capacity of the beam was being exceeded thereby leading to the chances of failure [15]. The effect of live load on safety margin of the timber bridge beam subjected to Shear and bearing forces was more significant in Shear.

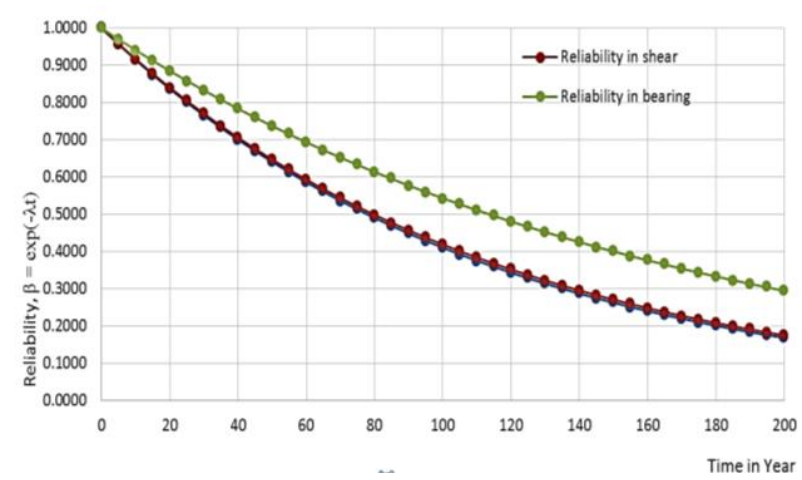

Figure 1: Reliability of Anogeissus schimperi Timber Bridge Beam

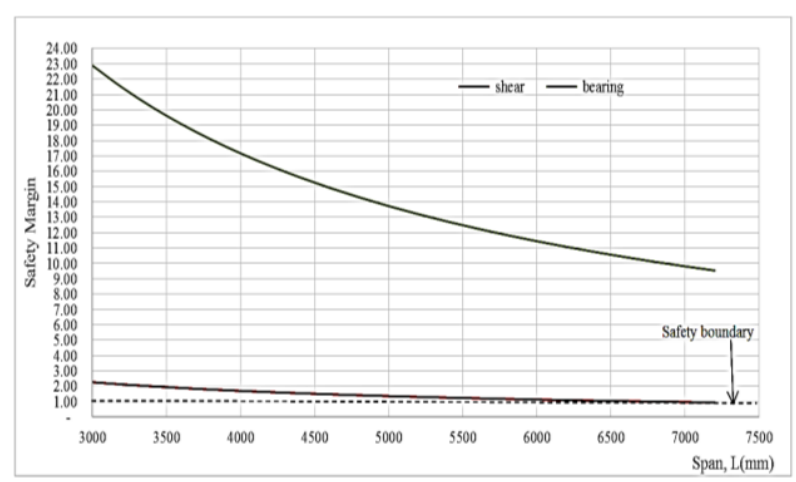

Figure 2 Variation in Span with the Safety Margin of Anogeissus Schimperi Timber Bridge Beam

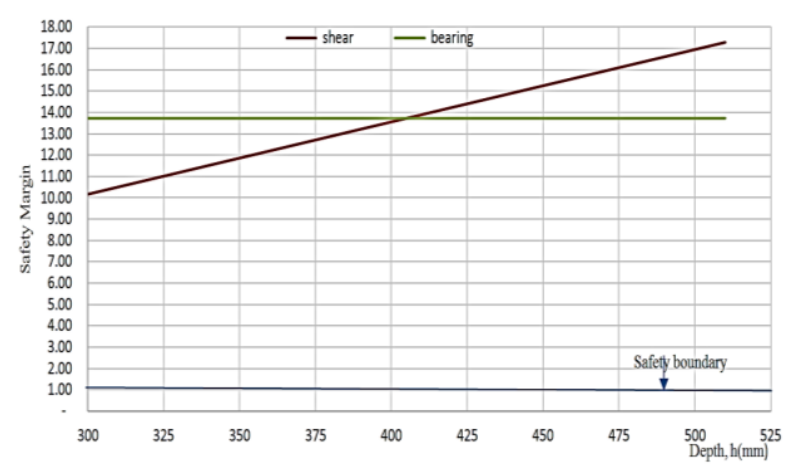

Figure 3 Variation in depth with the Safety Margin of Anogeissus Schimperi Timber Bridge Beam 


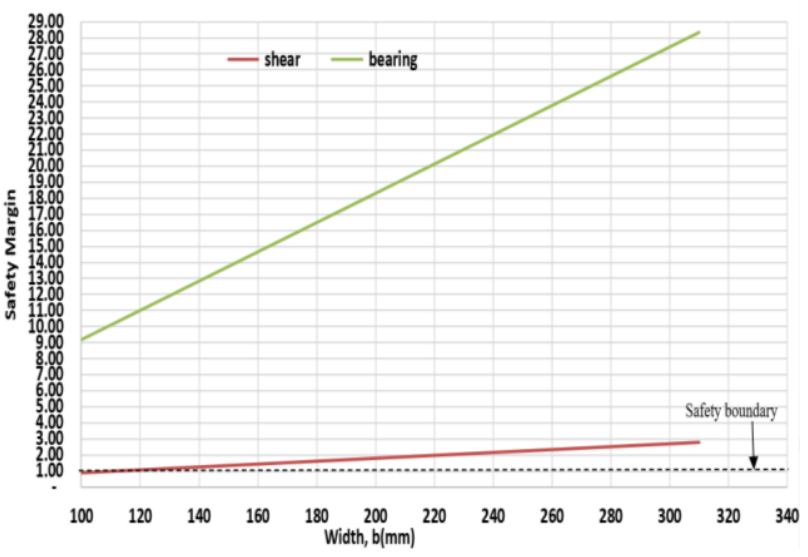

Figure 4: Variation in Width with the Safety Margin of Anogeissus Schimperi Timber Bridge Beam

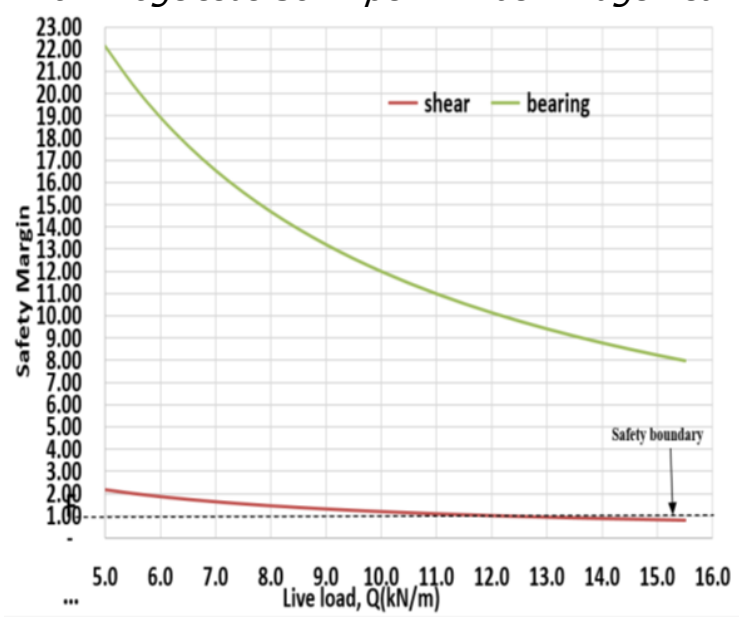

Figure 5:Variation in Live Load with the Safety Margin of Anogeissus Schimperi Timber Bridge Beam

\section{CONCLUSIONS}

Anogeissus schimperi timber specie had a reliability index of 0.65 and 0.73 in shear and bearing respectively which is greater than 0.5 , the minimum value for a reliable structure in line with [9] for 50year service period in Shear and bearing and can be used as reliable bridge beam material. Laboratory results of physical and mechanical properties obtained showed that Anogeissus schimperi specie is a Hardwood material. The result obtained can be compared with international standard.

Safety index was found to be directly proportional to the depth and width but inversely proportional to the span and live load of the timber bridge beam during Sensitivity Analysis, and the effect of change in Span and depth on safety margin were more significant in bearing.

\section{REFERENCES}

[1] Aguwa, J.I. Structural reliability of Nigerian grown abura timber bridge beam subjected to
Bending and Deflection forces, Nigeria Journal of Technology, 32(2), (2013) 241-252

[2] Aguwa J.I. Reliability Studies on the Nigerian Timber as Orthotropic Elastic Structural Material. Ph.D research submitted to PostGraduate School, Federal University of Technology, Minna, Nigeria (2010).

[3] Nowak A.S. and Saraf V., Reliability Analysis of Planks Decks for Bridges. Proceedings, National Reference on wooden Transport Structures, Madison WI, (1996) pp 225- 231.

[4] Aguwa J.I., Structural performance of Nigerian grown Abura timber bridge beam subjected to compression and shearing forces, Korean Society of Civil Engineers, KSCE J Civ. Eng.19, (2014), 974- 981.

[5] Han, S. H., A study on safety assessment of Cable-stayed bridge based on Stochastic Finite Element Analysis and Reliability. KSCE, Vol. 15, No 2 (2011) pp 305-315.

[6] Abubakar, P. and Nabade, A.M., Physical and mechanical properties of some common Nigeria timber species based on limit state design approach. Study of Civil Engineering and Architecture (2), (2013a) pp. 90-97.

[7] British Standards 373, (1957). Method of testing small clear specimens of timber. British Standard Institute, London.

[8] Izekor, D.N. and Nwankwo, A.S., Effects of density variations in the mechanical properties of plantation grown Tectonagrandis wood" Archives of applied science research. Vol. 2(6) (2010), pp114-120.

[9] Jimoh, et,.al., Reliability-based investigation on compressive strength characteristics of structural-sized Iroko (Milceae Excelsa) and Mahogany (KhayaIvorensis) Timber Column Found in Nigeria. Journal of Computational Engineering and Physical modeling 1-1 (2018), pp.23-37

[10] British Standards 5268,(2002). Structural use of timber, Part 2 code of practice for permissible stress design, materials and workmanship. British Standard Institute, London.

[11] Abubakar, P. and Nabade, A. M., Development of EN338 (2009), Strength classes for some common Nigeria Timber species using three point Shear test. International Journal of Civil, Architectural, Structural and Construction Engineering. 7(5) (2013b).

[12] Musa, S.A., Effect of moisture on strength of four different wood species commonly used in 
North Cyprus. M.Sc Thesis submitted to Department of Civil Engineering Near East University, Cyprus. . (2014) pp. 44-52, 70-72.

[13] Mohammed J. K (2009), Ph.D research on Reliability based analysis and calibration of Euro code5 design criteria for a solid timber portal frame.

[14] Aguwa et,.al., Characterization and Grading of South Eastern Nigerian grown Irvingia gabonensis Timber in accordance with BS 5268. Journal of Research Information in Civil Engineering, Vol. 12, No.2 (2015), pp. 720732.

[15] Aguwa, J.I. and Sadiku, S. Structural reliability analysis on the Nigerian Ekki Timber Bridge Beam Subjected to Bending force Under Ultimate Limit State. Research Journal in Engineering and Applied Sciences. Journal of Civil Engineering Instruction.2 (2), (2011). 253-259.

[16] Leitch, R. D. Basic reliability engineering analysis", 1st Edition, McGinley Publisher, (1988). pp. 13-86.

[17] Adedeji, A.A. Reliability- Based probability analysis for predicting failure of earth brick wall in compression, USEP. Research of Information in Civil Engineering. 3(2): (2008), pp. 213-221.

[18] Aguwa, J.I. Reliability assessment of the Nigerian Apa (AfzelieBipindensis) timber Bridge Beam Subjected to Bending and Deflection under ultimate limit state of loading". International Journal of Engineering and Technology.2 (6): (2012) pp. 1076-1088.

[19] Aguwa, J.I. and Sadiku, S. Structural reliability of Nigerian Grown Abura timber bridge beam subjected to Shear and bearing forces, Nigeria Journal Technology.32 (2), (2013) pp. 241252.

\section{APPENDIX}

Table 9: Variation in span with safety margin in shear and bearing.

\begin{tabular}{lll}
\hline Span, L(mm) & Shear & Bearing \\
\hline 3000 & 2.26 & 22.89 \\
3200 & 2.12 & 21.45 \\
3400 & 1.99 & 20.19 \\
3600 & 1.88 & 19.07 \\
3800 & 1.78 & 18.07 \\
4000 & 1.69 & 17.16 \\
4200 & 1.61 & 16.35 \\
4400 & 1.54 & 15.60
\end{tabular}

\begin{tabular}{lll}
\hline Span, L(mm) & Shear & Bearing \\
\hline 4600 & 1.47 & 14.93 \\
4800 & 1.41 & 14.30 \\
5000 & 1.36 & 13.73 \\
5200 & 1.30 & 13.20 \\
5400 & 1.26 & 12.71 \\
5600 & 1.21 & 12.26 \\
5800 & 1.17 & 11.84 \\
6000 & 1.13 & 11.44 \\
6200 & 1.09 & 11.07 \\
6400 & 1.06 & 10.73 \\
6600 & 1.03 & 10.40 \\
6800 & 1.00 & 10.10 \\
7000 & 0.97 & 9.81 \\
7200 & 0.94 & 9.54 \\
\hline
\end{tabular}

Table 10: Variation in depth with safety margin in shear and bearing

\begin{tabular}{lll}
\hline Depth, $\mathrm{h}(\mathrm{mm})$ & Hear & Bearing \\
\hline 300 & 10.17 & 13.73 \\
310 & 10.51 & 13.73 \\
320 & 10.85 & 13.73 \\
330 & 11.18 & 13.73 \\
340 & 11.52 & 13.73 \\
350 & 11.86 & 13.73 \\
360 & 12.20 & 13.73 \\
370 & 12.54 & 13.73 \\
380 & 12.88 & 13.73 \\
390 & 13.22 & 13.73 \\
400 & 13.56 & 13.73 \\
410 & 13.90 & 13.73 \\
420 & 14.24 & 13.73 \\
430 & 14.57 & 13.73 \\
440 & 14.91 & 13.73 \\
450 & 15.25 & 13.73 \\
460 & 15.59 & 13.73 \\
470 & 15.93 & 13.73 \\
480 & 16.27 & 13.73 \\
490 & 16.61 & 13.73 \\
500 & 16.95 & 13.73 \\
510 & 17.29 & 13.73 \\
\hline & & \\
\hline
\end{tabular}


Structural Reliability-Based Assessment of Nigerian Anogeissusschimperi Timber Bridge Beam in Shear Bearing, P. Abubakar, et al

Table 11: Variation in width with safety margin in shear and bearing

\begin{tabular}{lll}
\hline Width, $\mathrm{b}(\mathrm{mm})$ & shear & bearing \\
\hline 100 & 0.90 & 9.15 \\
110 & 0.99 & 10.07 \\
120 & 1.08 & 10.98 \\
130 & 1.17 & 11.90 \\
140 & 1.27 & 12.82 \\
150 & 1.36 & 13.73 \\
160 & 1.45 & 14.65 \\
170 & 1.54 & 15.56 \\
180 & 1.63 & 16.48 \\
190 & 1.72 & 17.39 \\
200 & 1.81 & 18.31 \\
210 & 1.90 & 19.22 \\
220 & 1.99 & 20.14 \\
230 & 2.08 & 21.05 \\
240 & 2.17 & 21.97 \\
250 & 2.26 & 22.89 \\
260 & 2.35 & 23.80 \\
270 & 2.44 & 24.72 \\
280 & 2.53 & 25.63 \\
290 & 2.62 & 26.55 \\
300 & 2.71 & 27.46 \\
310 & 2.80 & 28.38 \\
\hline
\end{tabular}

Table 12: Variation in live load with safety margin in shear and bearing

\begin{tabular}{lll}
\hline Live load, $q(\mathrm{~N} / \mathrm{mm})$ & Shear & Bearing \\
\hline 5.0 & 2.19 & 22.13 \\
5.5 & 2.01 & 20.40 \\
6.0 & 1.87 & 18.93 \\
6.5 & 1.74 & 17.65 \\
7.0 & 1.63 & 16.53 \\
7.5 & 1.54 & 15.55 \\
8.0 & 1.45 & 14.68 \\
8.5 & 1.37 & 13.90 \\
9.0 & 1.30 & 13.20 \\
9.5 & 1.24 & 12.56 \\
10.0 & 1.18 & 11.99 \\
10.5 & 1.13 & 11.46 \\
11.0 & 1.08 & 10.98 \\
11.5 & 1.04 & 10.54 \\
12.0 & 1.00 & 10.13 \\
12.5 & 0.96 & 9.75 \\
13.0 & 0.93 & 9.40 \\
13.5 & 0.90 & 9.07 \\
14.0 & 0.87 & 8.77 \\
14.5 & 0.84 & 8.48 \\
15.0 & 0.81 & 8.22 \\
15.5 & 0.79 & 7.97 \\
\hline
\end{tabular}

